\title{
Zoospore Density-Dependent Behaviors of Phytophthora nicotianae Are Autoregulated by Extracellular Products
}

\author{
Ping Kong and Chuanxue Hong
}

Department of Plant Pathology, Physiology and Weed Science, Virginia Polytechnic Institute and State University, 1444 Diamond Springs Road, Virginia Beach 23455-3363.

Accepted for publication 6 March 2010.

\section{ABSTRACT}

Kong, P., and Hong, C. 2010. Zoospore density-dependent behaviors of Phytophthora nicotianae are autoregulated by extracellular products. Phytopathology 100:632-637.

\begin{abstract}
Phytophthora species are destructive fungus-like plant pathogens that use asexual single-celled flagellate zoospores for dispersal and plant infection. Many of the zoospore behaviors are density-dependent although the underlying mechanisms are poorly understood. Here, we use P. nicotianae as a model and demonstrate autoregulation of some zoospore behaviors using signal molecules that zoospores release into the environment. Specifically, zoospore aggregation, plant targeting, and infection required or were enhanced by threshold concentrations of these signal molecules. Below the threshold concentration, zoospores did not aggregate and move
\end{abstract}

toward a cauline leaf of Arabidopsis thaliana (Col-0) and failed to individually attack annual vinca (Catharanthus roseus cv. Little Bright Eye). These processes were reversed when supplemented with zoosporefree fluid (ZFF) prepared from a zoospore suspension above threshold densities but not with calcium chloride at a concentration equivalent to extracellular $\mathrm{Ca}^{2+}$ in ZFF. These results suggest that $\mathrm{Ca}^{2+}$ is not a primary signal molecule regulating these communal behaviors. Zoospores coordinated their communal behaviors by releasing, detecting, and responding to signal molecules. This chemical communication mechanism raises the possibility that Phytophthora plant infection may not depend solely on zoospore number in the real world. Single zoospore infection may take place if it is signaled by a common molecule available in the environment which contributes to the destructiveness of these plant pathogens.
The genus Phytophthora comprises about 100 species of destructive pathogens that attack a broad range of economically important agricultural and ornamental crops as well as forest tree species $(10,11,13)$. Phytophthora species produce flagellate singlecelled zoospores as their primary dispersal and infection agents $(6,9,23)$, and many zoosporic behaviors are density-dependent. For example, single zoospores seldom colonize even under optimal conditions (4). Zoospores aggregate only at or above 2 to $5 \times$ $10^{5} \mathrm{ml}^{-1}$ for P. palmivora (31), 1 to $2 \times 10^{5} \mathrm{ml}^{-1}$ for $P$. capsici (25), and $\geq 5 \times 10^{5} \mathrm{ml}^{-1}$ for $P$. infestans (28). Similarly, plant infection by Phytophthora species requires certain densities of inoculum although the threshold is much lower compared with that needed for aggregation; this threshold density varies from species to species $(12,24,28,29,37)$. It is not yet clear how such communal behaviors are regulated.

Calcium has been thought of as a regulating molecule responsible for many zoosporic behaviors since zoospores can produce this molecule during encystment $(21,38)$, and many zoospore behaviors including autoaggregation and plant infection can be affected by exogenous calcium or calcium inhibitors $(6,31,36,37)$. For example, cyst germination can be induced by $\mathrm{CaCl}_{2}$ or a zoospore-free suspension which may contain calcium released from zoospores (5). This process may be inhibited by calcium antagonists, then restored by adding $\mathrm{CaCl}_{2}$ (38). Similarly, zoospore aggregation is thought to be calcium-dependent because addition of calcium antagonists to a zoospore suspension inhibits this process (31), although it is not known whether this process is affected directly by calcium. Effects of calcium on some zoospore

Corresponding author: P. Kong; E-mail address: pkong@vt.edu

* The $e$-Xtra logo stands for "electronic extra" and indicates that Figure 3 appears in color online.

doi:10.1094/PHYTO-100-7-0632

(C) 2010 The American Phytopathological Society behaviors are concentration-dependent; higher concentrations suppress zoospore motility (3) and hamper plant diseases caused by Phytophthora (37), while lower concentrations induce zoospore production, cyst germination, and adhesion $(8,15,16)$.

In this study, we use $P$. nicotianae (synonym: $P$. parasitica) as a model to investigate regulation of zoospore communal behaviors. $P$. nicotianae infects more than 800 plant species and causes root and foliage damage although it has not been reported to infect Arabidopsis plants $(10,33)$. Zoospore plant infection is known to be associated with concentration of inocula, and zoospore aggregation is thought to be a factor that can increase the infection potential $(19,37)$. We hypothesize that zoospore aggregation, plant targeting, and infection behaviors are coordinated through zoospore extracellular products. We demonstrate that zoospores detect and respond to the extracellular products in zoospore-free fluid (ZFF) to regulate their communal behaviors. The effect of calcium as a signal molecule for zoospore aggregation and plant infection is also examined. This study advances our understanding of chemical communication as a potentially important factor in the infection of plants by Phytophthora species.

\section{MATERIALS AND METHODS}

Preparation of ZFF. $P$. nicotianae isolate $1 \mathrm{~B} 11$ was used for ZFF preparation. First, the 1- to 2-week-old culture on clarified $20 \%$ V8 agar (CV8) (32) was cut into $5-\mathrm{mm}^{2}$ plugs, and two plugs were added to each 90 -mm-diameter petri dish with $10 \%$ CV8 broth and incubated at $23^{\circ} \mathrm{C}$ in the dark for 2 weeks to induce production of sporangia. After the seed plugs and medium were removed, the mycelial mats were rinsed five times with sterile distilled water (SDW) to eliminate nutrients from the remaining medium. The drained mycelial mats were incubated for 1 week under fluorescent light at $23^{\circ} \mathrm{C}$. For zoospore release, the mats with numerous sporangia were rinsed an additional five times with SDW and then flooded with $8 \mathrm{ml}$ of chilled SDW and kept 
under light for $1 \mathrm{~h}$. Zoospore density was usually $10^{6} \mathrm{ml}^{-1}$ unless otherwise stated. All procedures were performed under sterile conditions to prevent bacterial contamination. Finally, to obtain ZFF, zoospore suspensions were filtered through sterile miracloth to remove mycelia, sporangia, and other structures, followed by vortexing briefly to facilitate chemical release (21). The suspensions were then filtered through a $0.2-\mu \mathrm{m}$ syringe filter to remove the cysts. ZFF was used fresh or from storage at $-20^{\circ} \mathrm{C}$.

Fresh zoospore production for microscopy and inoculation assays. To produce zoospores rapidly, a dozen culture plugs were flooded with $1 \%$ sterile soil-water extract in a 90 -mm-diameter petri dish for 8 to $16 \mathrm{~h}$. The plugs were then rinsed three times with SDW and placed under fluorescent lights overnight to induce sporangium production. To facilitate zoospore release from the sporangia and eliminate nutrients from the plugs, the plugs were further rinsed three times with chilled SDW and incubated in SDW for up to $1 \mathrm{~h}$. Zoospore density was determined using a hemacytometer under a light microscope, and the suspension was diluted with SDW to a stock concentration of $10^{4}$ zoospores $\mathrm{ml}^{-1}$ for further applications.

Analysis of zoospore aggregation. Zoospore aggregation was examined under an IX71 inverted microscope (Olympus America Inc., PA). In preliminary studies, zoospores in SDW did not aggregate at densities below $5 \times 10^{5} \mathrm{ml}^{-1}$. To determine the effects of ZFF and calcium on zoospore aggregation, zoospore suspensions at $2 \times 10^{3} \mathrm{ml}^{-1}$ were used. Suspensions were made by mixing $30 \mu \mathrm{l}$ of zoospore suspension stock at $10^{4}$ zoospores $\mathrm{ml}^{-1}$ with $120 \mu \mathrm{l}$ of a test solution in a $150-\mu \mathrm{l}$ depression slide well. Test solutions included $\mathrm{ZFF}$, dilution series of $\mathrm{CaCl}_{2}$ from $10 \mathrm{mM}$, and $10^{4} \times$ diluted CV8 broth. Slides with zoospore suspensions were incubated on wet filter paper in $10-\mathrm{cm}$-diameter petri dishes at $23^{\circ} \mathrm{C}$. Zoospores in two wells were examined under the microscope for activity in six fields at $1,4,16,24$, and $48 \mathrm{~h}$ of incubation. Zoospores that aggregated or formed clumps in all three observation fields per well were recorded as aggregation positive. Zoospore motility and germination rates were also recorded. Images were captured with the Image-Pro Plus software version 5.1 (Media Cybernetics, Inc., MA). Each test was done twice.

Analysis of zoospore plant targeting. The effect of ZFF on zoospore chemotaxis to plants was tested by exposing a low density of $1.6 \times 10^{3} \mathrm{ml}^{-1}$ of zoospores to plant tissue. An aliquot of $40 \mu \mathrm{l}$ of fresh zoospore-suspension stock at $10^{4} \mathrm{ml}^{-1}$ was mixed with $210 \mu \mathrm{l}$ of ZFF or SDW in a well of 24 -well plates. A detached cauline leaf from 6-week-old Arabidopsis thaliana (Col-0) seedlings grown in Metro Mix 200 (Sun Grow Horticulture, Bellevue, WA) in a growth chamber was then added to the suspension. The treatment plates were kept at $23^{\circ} \mathrm{C}$ and zoospore development was examined over a period of 5 days. Images were captured as described for aggregation tests. The test included three wells per treatment and was done three times.

Zoospore plant infection assay. Several assays were performed with annual vinca (Catharanthus roseus cv. Little Bright Eye). Four-week-old seedlings were transplanted in pine bark and then grown for 4 to 6 weeks in a greenhouse. Prior to inoculation, leaves were detached from plants, surface-sterilized with $70 \%$ ethanol, and rinsed in SDW to minimize potential interference from other microbes before placement on glass rods in plastic containers. All inoculations were done by applying ten $10-\mu l$ drops of inoculum to different sites on the underside of each leaf. To determine zoospore density dependence of plant infection, a fresh zoospore-suspension stock at $10^{4} \mathrm{ml}^{-1}$ was applied undiluted or $10 \times$ or $100 \times$ diluted with SDW (i.e., 10 and 1 zoospore per $10-\mu \mathrm{l}$ drop). To examine the effects of extracellular products, $\mathrm{Ca}^{2+}$, and nutrient residues from media, the zoospore suspension stock was diluted with a test solution to $100 \mathrm{ml}^{-1}$ so that each $10-\mu \mathrm{l}$ drop of inoculum would contain approximately one zoospore. Test solutions included ZFF, dilution series of $\mathrm{CaCl}_{2}$ from $10 \mathrm{mM}, 10^{4} \times$ diluted CV8 broth, and SDW. Inoculated leaves were kept in a moist chamber and incubated in the dark overnight at $23^{\circ} \mathrm{C}$ followed by an additional 3 days with a $10-\mathrm{h} /$ 14-h day/night cycle in a growth chamber. Inoculated sites developing water-soaked lesions during the $72 \mathrm{~h}$ incubation time were recorded as infected. Each test included six replicate leaves and was done three to six times. The disease incidence data from these tests were pooled after analysis of homogeneity and then analyzed to determine the significance of difference among treatments using analysis of variance (SAS Institute, Cary, NC).

\section{RESULTS}

Extracellular products mediate zoospore aggregation. As illustrated in Figure 1A, zoospores in SDW aggregated only at $5 \times$ $10^{5} \mathrm{ml}^{-1}$ or higher densities. To examine whether the autoaggregation is mediated through molecules released from zoospores, a fresh zoospore suspension stock was diluted to $2 \times$ $10^{3} \mathrm{ml}^{-1}$ with ZFF, CV8 broth, or SDW. At this density, 250-fold lower than the threshold, only those zoospores in ZFF aggregated. Zoospores gradually moved together and formed clusters of cysts (Fig. 1B and C). In contrast, zoospores in SDW (Fig. 1D and E) or diluted CV8 broth at the same density did not aggregate. Many of the zoospores remained swimming after $4 \mathrm{~h}$ incubation in SDW (Fig. 1D). More than $30 \%$ of zoospores in the suspension germinated in the diluted CV8 after overnight incubation (Fig. 1F). These results indicate that zoospore aggregation was coordinated chemically by zoospore-extracellular products rather than nutrient residues from media.

Extracellular products affect zoospore plant targeting. Zoospores target plants by chemotaxis. Previously this was attributed to chemotactic substances from plants (6). To determine whether zoospores themselves play a role in this process, activities of $P$. nicotianae zoospores in SDW or ZFF at a low density of $1.6 \times$ $10^{3} \mathrm{ml}^{-1}$ were examined in the presence of an Arabidopsis cauline leaf. Clumps of encysted zoospores or cysts were observed on the leaf surface, especially on trichomes, in wells containing ZFF after $4 \mathrm{~h}$ incubation (Fig. 2A). In contrast, zoospores at the same density and incubation time did not cluster on plant tissue in control wells containing only SDW; they scattered randomly in the wells (Fig. 2B). This indicates that zoospore taxis to and settlement on plant tissue was mediated through their own extracellular products instead of those from plants. Comparison of cyst germination with and without plant tissue implies that plant exudates induced germination of cysts irrespective of presence or absence of ZFF. With plant tissue the germination rates were up to $90 \%$, while without plant tissue few cysts germinated in either ZFF (Fig. 1B and C) or SDW (Fig. 1D and E) even with further incubation. More germlings were observed on the leaf surface in presence of ZFF which produced sporangia in or on the plant tissue after 5 days of incubation (Fig. 2C). This was dramatically different from incubation of the same numbers of zoospores in SDW (Fig. 2D). These results indicate that extracellular products of zoospores played a primary role in zoospore taxis to and infection of plant tissue.

Extracellular products regulate plant infection by zoospores. Plant infection by $P$. nicotianae in SDW was densitydependent (Fig. 3A). The infection rate on the inoculation sites dropped with decreasing number of zoospores per site, and single-zoospore inoculation resulted in little infection. More than $20 \%$ of the sites did not develop any symptoms with 100 zoospores per site, indicating the requirement of a higher density of zoospores for an optimal infection rate under this condition.

To determine whether zoospore infection is mediated by a chemical communication process through signaling molecules from zoospores, single zoospore inoculation was conducted. After $72 \mathrm{~h}$ incubation, few sites inoculated with single zoospores in diluted CV8 or SDW developed a lesion (Fig. 3B [left] and C, Fig. 4D). In contrast, more than $70 \%$ of sites inoculated with 
single zoospores in ZFF developed lesions. This rate was nearly as high as that obtained with 100 zoospores in SDW (Fig. 3B). When ZFF was diluted, plant infection rates from single-zoospore inoculation decreased (Fig. 3C). Thus, a single zoospore may infect a plant as long as there is adequate signals in the environment.

Effects of exogenous $\mathrm{Ca}^{2+}$ on zoosporic communal behaviors. To determine whether $\mathrm{Ca}^{2+}$ is used for communication of zoospores in zoospore aggregation and plant infection, $\mathrm{CaCl}_{2}$ at different concentrations was tested as was done for ZFF. Unexpectedly, zoospores did not aggregate in $\mathrm{CaCl}_{2}$ solutions at any of the concentration range tested (Fig. 4B and C). Most cysts, irrespective of $\mathrm{Ca}^{2+}$ concentration, scattered in the wells of depression slides and germinated after overnight incubation as in diluted CV8 broth (Fig. 1F). The germination rate decreased with decreasing concentrations of $\mathrm{Ca}^{2+}$.

Similarly, inoculation with single zoospore in $\mathrm{CaCl}_{2}$ solutions resulted in infection of fewer sites on detached annual vinca leaves compared with that in ZFF. The infection rate decreased with decreasing $\mathrm{Ca}^{2+}$ concentration (Fig. 4D). The highest infection rate, obtained with $\mathrm{CaCl}_{2}$ at $10 \mathrm{mM}$, was significantly $(P<0.0001)$ lower than the rates with ZFF $(20 \%$ versus $65 \%)$. The $\mathrm{Ca}^{2+}$ concentration in the ZFF should be no more than
$500 \mathrm{nM}$ as calculated according to a previous study (38). Therefore, molecules other than $\mathrm{Ca}^{2+}$ in ZFF were responsible for signaling zoospore aggregation and plant infection.

\section{DISCUSSION}

Density-dependent behavior in bacteria is controlled by a process called "quorum sensing," a cell-to-cell communication mechanism by which bacteria count their own numbers by producing and detecting the accumulation of a signaling molecule or autoinducer that they release into the environment $(14,39)$. Such a mechanism controls bacterial processes including biofilm formation, virulence-factor secretion, and sporulation as well as pathogenicity and plant colonization (34). Quorum sensing also has been documented in fungi and regulates processes such as dimorphism and biofilm formation, although fungal species use completely different autoinducers from those employed by bacteria (18). Processes controlled by quorum sensing have one thing in common: they are unproductive when undertaken by a single individual but become effective when undertaken by the group. They are all coordinated by the extracellular products or autoinducers (39). This study has demonstrated that quorum sensing operates in $P$. nicotianae, regulating zoospore aggrega-

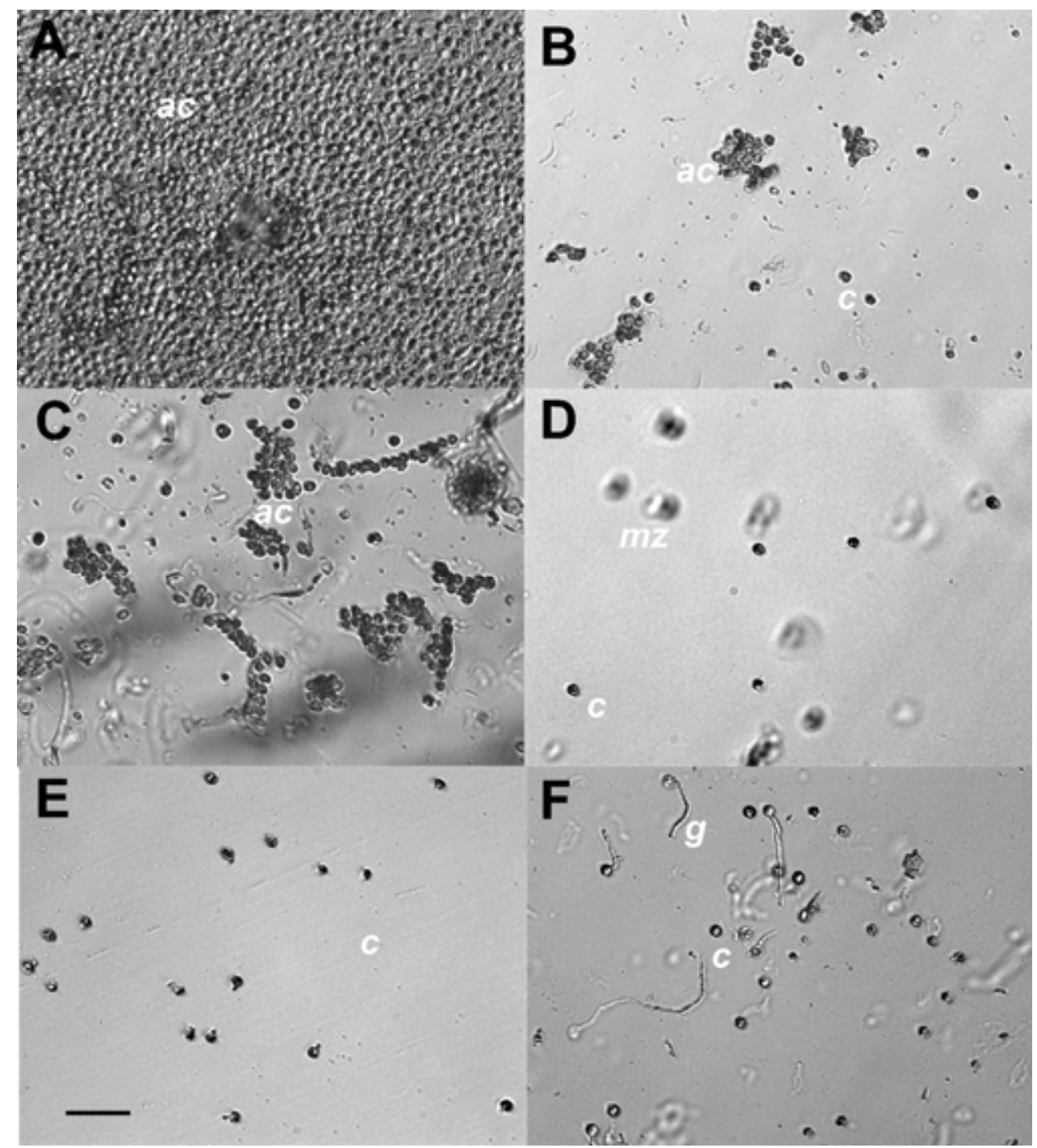

Fig. 1. Effect of zoospore-free fluid (ZFF) on zoospore aggregation of Phytophthora nicotianae. Zoospore suspension was incubated in depression slide wells containing a test solution of $150 \mu \mathrm{l}$ at $23^{\circ} \mathrm{C}$. Zoospores in sterile distilled water (SDW) at $2 \times 10^{6} \mathrm{ml}^{-1}$ aggregated after A, 16-h incubation. Zoospores in ZFF at $2 \times 10^{3} \mathrm{ml}^{-1}$ aggregated after $\mathbf{B}, 4 \mathrm{~h}$ and $\mathbf{C}, 16 \mathrm{~h}$ incubation, but not in SDW at the same density and incubation times $\left(\mathbf{D}\right.$ and E), nor did those in $10^{4} \times$ diluted CV8 broth medium after F, $16 \mathrm{~h}$. Six fields were examined for each treatment point. Images were captured from representative fields under an inverted microscope. Bar $=50 \mu \mathrm{m} . c=$ cyst, $m z=$ motile zoospore, $a c=$ aggregated cyst, $g=$ germinant. 
tion, targeting, and infection of annual vinca and Arabidopsis. These data support the contention that cell chemical communication is a fundamental microbiological mechanism operating beyond the bacterial world (1).

We provide the first experimental evidence that zoospore chemical communication is an important factor in the infection process. $P$. nicotianae zoospores in the ZFF can aggregate on the leaf surface at a low density (Fig. 2A) and subsequently germinate and penetrate plant tissue (Fig. 2C). They do not target or attack a plant when the signal molecules are below the threshold level. When chemical signals in the environment reach the threshold concentration, zoospores initiate the taxis and infection processes. These molecules from zoospores and maybe other structures of Phytophthora are functionally different from those in plant exudates or nutrients that stimulate cyst germination (7). They serve as autoinducers which regulate zoospore aggregation, taxis, and infection.

Chemical communication may give zoosporic plant pathogens advantages in their fitness and pathogenesis. For example, it may direct $P$. nicotianae zoospores to work synchronically as they target plants and aggregate on the plant surface (Fig. 2A) (17). Such team work will subsequently facilitate plant infection. How- ever, how this communication mechanism works to the advantage of Phytophthora species in the real world remains unclear. $P$. nicotianae constantly causes disease problems in nurseries, but it was infrequently detected in its primary inoculum sources (e.g., in irrigation water) because of its low population density $(2,20,26)$. The lack of zoospore detection before disease epidemics may imply the unlikelihood of aggregation as a mechanism for primary infection. Aggregation may only facilitate further cycles of infection as zoospores accumulate after sporangium production in infected plant tissue at a later stage of infection (37). Alternatively, aggregation may serve other roles in zoosporic pathogen biology, such as biofilm formation for drug resistance as described for bacterial and fungal species (30), which deserves further investigation.

The lack of zoospore detection before infection also raises a question about the ability of zoospores at low density to infect plants in the environment. There are three possibilities. First, the pathogens may increase the concentration of the autoinducer by increasing zoospore numbers in the environment. Zoospore number before infection can be increased through secondary zoospore production as that occurs in irrigation water systems (35). Zoospore number can also be increased through disease cycles.
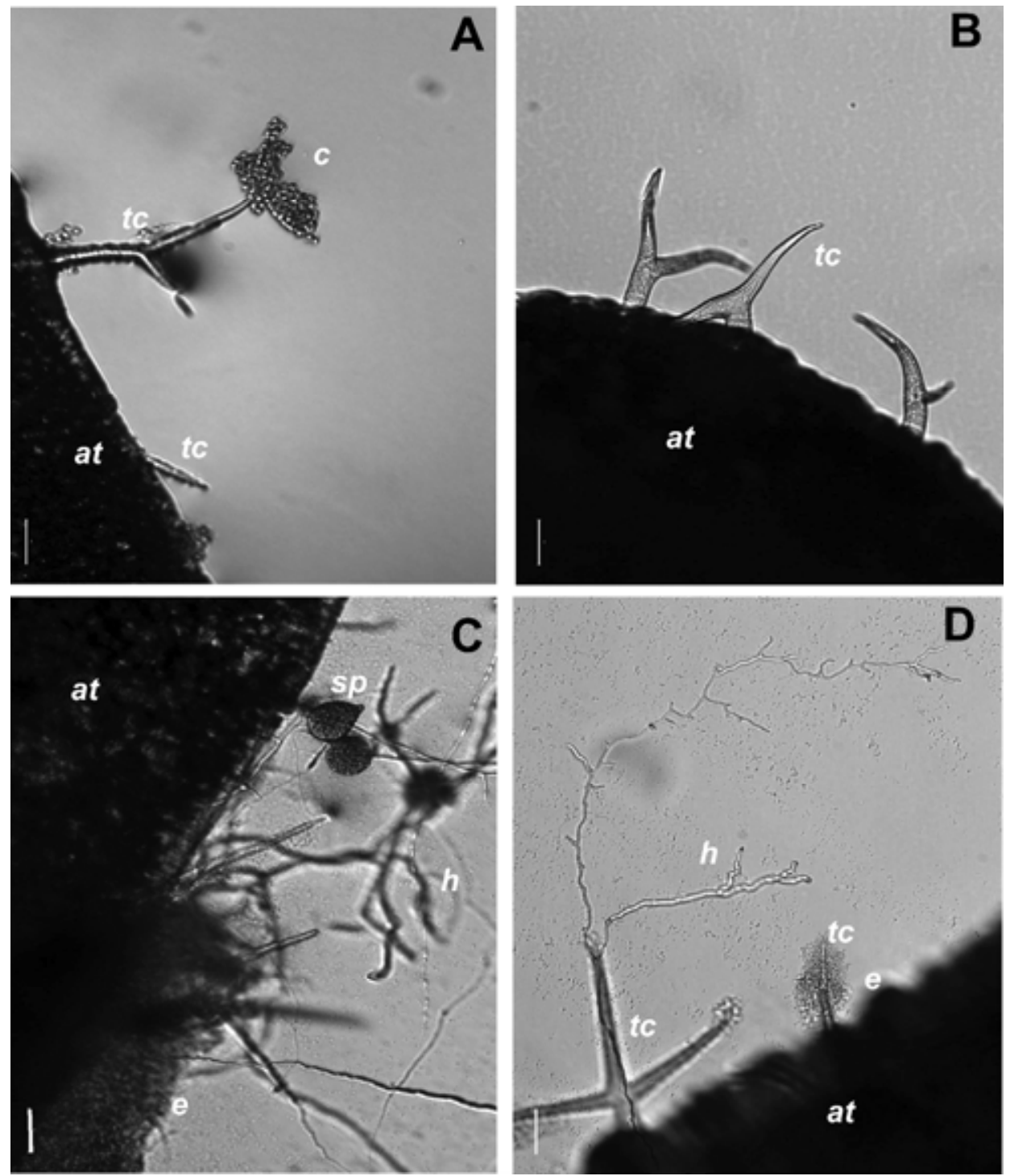

Fig. 2. Effect of zoospore-free fluid (ZFF) on zoospore plant targeting. Phytophthora nicotianae zoospore suspension at $1.6 \times 10^{3} \mathrm{ml}^{-1}$ was incubated at $23^{\circ} \mathrm{C}$ in wells of a 24-well plate, each containing a test solution of $250 \mu$. Zoospores in ZFF aggregated and encysted on a cauline leaf of Arabidopsis thaliana (Col-0) after $\mathbf{A}, 4 \mathrm{~h}$ and $\mathbf{C}$, differentiated after 5 days, in contrast with zoospore behaviors in sterile distilled water at the same time points $(\mathbf{B}$ and $\mathbf{D})$. Six fields were examined for each treatment point. Images were captured from representative fields under an inverted microscope. Bar $=50 \mu \mathrm{m}$. $a t=$ Arabidopsis leaf tissue, $c=$ cyst, $\mathrm{e}=$ exudates from plant tissue, $h=$ hypha or germling, $t c=$ trichome, $s p=$ sporangium 
Once primary infection succeeds, thousands of zoospores will release from diseased plant tissue (10). Second, cysts around or on plant tissue may not attack a plant immediately but they may weaken plants so that other structures from them, such as infection hyphae, may directly infect plants. We observed exudates releasing from tissue incubated in not only ZFF but also SDW with a low density of zoospores (Fig. 2C and D). The infection by zoospores in SDW was delayed or attenuated and did not result in sporangia 5 days after treatment. Third, the chemical signals for zoospore communication and plant infection may already exist in natural environments. We recently found that AI-2, a universal autoinducer of bacteria, can be produced by plant zoosporic pathogens (27). This suggests that AI-2 available in environments may be shared by these pathogens if this signaling molecule can be used to regulate communal behaviors of zoosporic oomycetes, which remains to be determined.

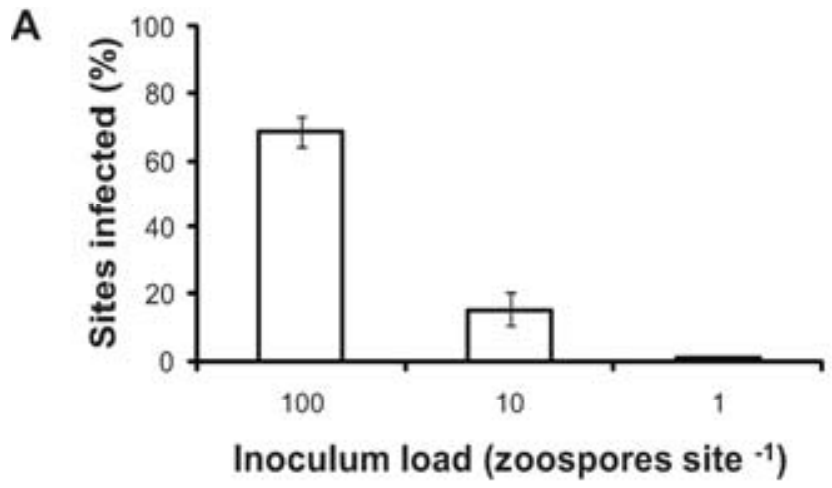

B
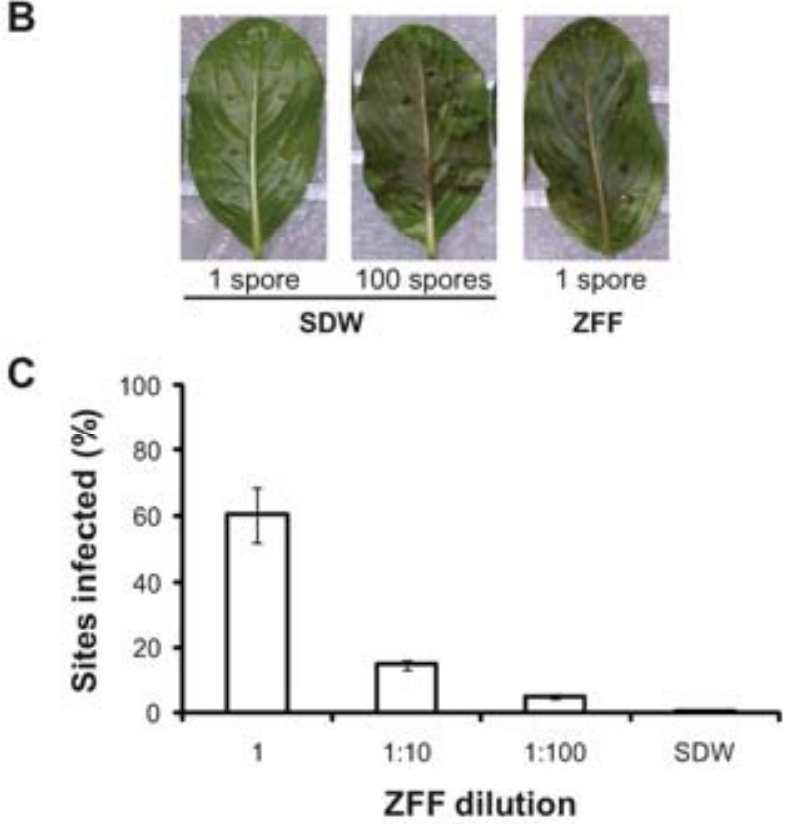

Fig. 3. Effect of zoospore density and concentration of zoospore-free fluid (ZFF) on zoospore plant infection. Ten 10- $\mu$ l drops of Phytophthora nicotianae zoospore inoculum prepared in ZFF were placed at 10 different sites on the underside of each leaf of annual vinca (Catharanthus roseus). Inoculated sites were assessed for infection after 3-day incubation at $23^{\circ} \mathrm{C}$. A, Densitydependent infection by zoospores suspended in sterile distilled water (SDW). Each column is a mean percentage of sites diseased from 36 replicate leaves in six independent tests and is topped with a standard error bar. B, Blight symptoms on a representative leaf inoculated with 10 drops of ZFF containing approximately one zoospore each compared with those on the leaf inoculated with 10 drops of SDW containing 1 or 100 zoospores each. C, Decreased infection with dilution of ZFF. Each column is a mean percentage of sites diseased from 36 replicate leaves in six independent tests and is topped with a standard error bar.
In addition to AI-2, other molecules may also act as autoinducers for zoospore chemical communication in oomycetes. Calcium, for example, is produced by zoosporic pathogens and is also widespread in nature. However, in this study, we found that the processes stimulated by $\mathrm{Ca}^{2+}$ were different in many ways from those triggered by ZFF. We examined the effect of $\mathrm{Ca}^{2+}$ on zoospore aggregation and plant infection by addition of $\mathrm{CaCl}_{2}$ at different concentrations to a zoospore suspension. First, we found that $\mathrm{CaCl}_{2}$ did not induce zoospore autoaggregation at any concentration tested (Fig. 4A to D). Second, $\mathrm{CaCl}_{2}$ did not trigger single-zoospore infection at the concentration equivalent to extracellular $\mathrm{Ca}^{2+}$ in ZFF (Fig. 4D). In contrast, it stimulated cyst germination and induced a low level of plant infection by $P$. nicotianae at a $\mathrm{Ca}^{2+}$ level $20,000 \times$ higher than that in $\mathrm{ZFF}$, which was shown to contain $500 \mathrm{nM} \mathrm{Ca}^{2+}$ when the zoospore density was $10^{6} \mathrm{ml}^{-1}$ (38). These results suggest that released extracellular
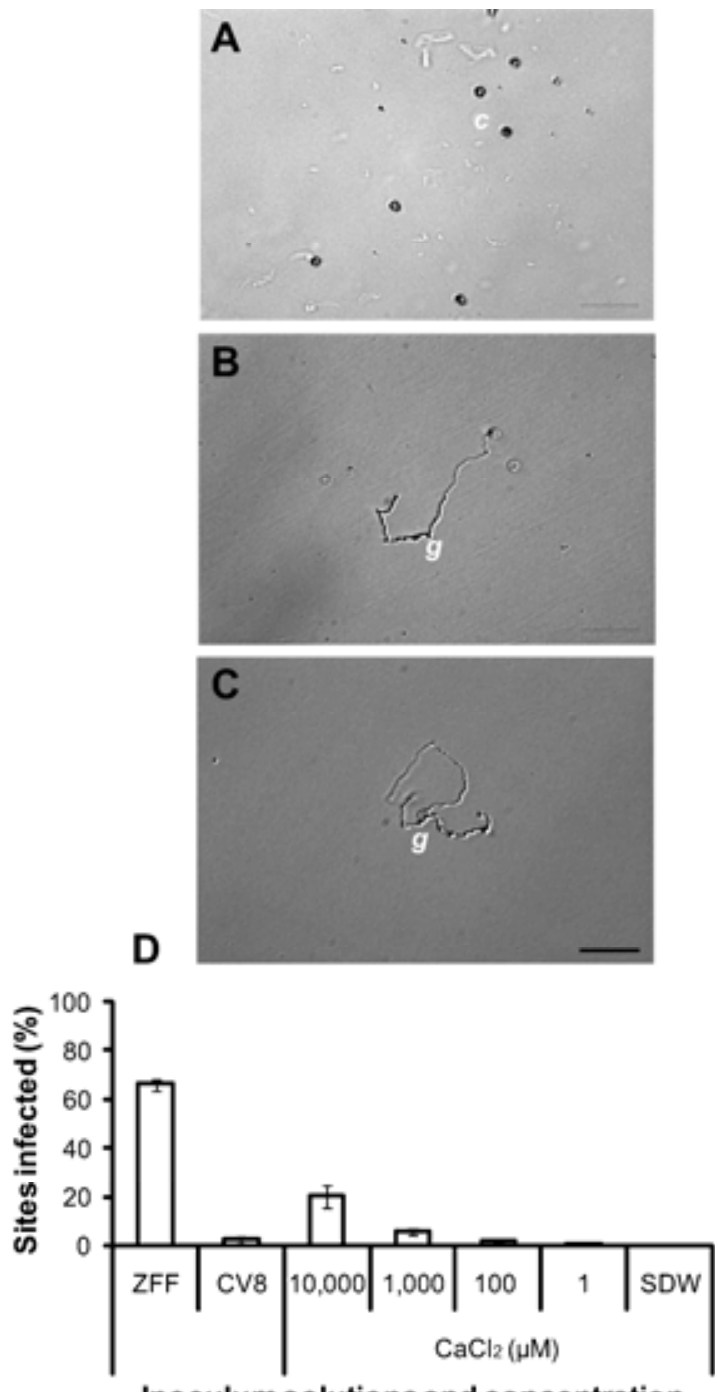

Inoculum solutions and concentration

Fig. 4. Effect of $\mathrm{Ca}^{2+}$ on zoospore behavior and plant infection by Phytophthora nicotianae. Zoospores were incubated in a $150-\mu l$ test solution at $2 \times 10^{3} \mathrm{ml}^{-1}$ in depression-slide wells at $23^{\circ} \mathrm{C}$. Zoospores in A, sterile distilled water (SDW), $\mathbf{B}, \mathrm{CaCl}_{2}$ at $1 \mu \mathrm{M}$, and $\mathbf{C}, 10 \mathrm{mM}$ overnight did not aggregate. Six fields were examined for each treatment point. Images were captured from representative fields under an inverted microscope. Bar $=50 \mu \mathrm{m} . c$ and $g$ indicate cyst and germlings, respectively. $\mathbf{D}$, Comparison of infection rates by single zoospores in zoospore-free fluid (from zoospore suspension at $5 \times$ $\left.10^{5} \mathrm{ml}^{-1}\right), 10^{4} \times$ diluted CV8 broth, $\mathrm{CaCl}_{2}$ dilutions, and SDW. Ten 10- $\mu \mathrm{l}$ drops containing a single zoospore each were placed at 10 different sites on the underside of each leaf of annual vinca (Catharanthus roseus). Each column is a mean percentage of sites diseased from 18 replicate leaves in three independent tests and is topped with a standard error bar. 
$\mathrm{Ca}^{2+}$ is not responsible for the regulation of communal behaviors in terms of $\mathrm{Ca}^{2+}$ concentration. However, $\mathrm{Ca}^{2+}$ has been proposed as a secondary messenger in chemical communication of Ulva intestinalis zoospores using a bacterial AHL autoinducer (22), and aggregation can be abolished using $\mathrm{Ca}^{2+}$ antagonists (31), the precise role of $\mathrm{Ca}^{2+}$ in Phytophthora zoospore-communal behavior is yet to be determined.

The chemical components of ZFF beyond AI-2 and $\mathrm{Ca}^{2+}$ are under investigation. ZFF was carefully prepared to eliminate nutrients from media and bacterium contamination. Mycelial mats in culture media were rinsed thoroughly before and after sporangium induction. The dilution factor by SDW in the CV8 broth was $10^{9}$ at the time of zoospore release (27). The concentration of CV8 broth used in zoospore aggregation and single zoospore infection assays was $10^{4}, 10^{5} \times$ higher than what may be present in ZFF. The diluted CV8 stimulated zoospore germination similar to $\mathrm{CaCl}_{2}$ but did not stimulate aggregation and single zoospore infection (Figs. 1F and 4D). In fact, the fresh zoospore suspensions prepared for all the assays also contained minimum medium residues, but these zoospores were not active in aggregation, plant targeting and infection until ZFF was added. To determine the effect of other factors such as miracloth and filters, we compared ZFF supernatant prepared by centrifugation at $10,000 \mathrm{rpm}$ with ZFF prepared by filtration. No differences were observed between these two preparations (data not shown), demonstrating that the active components in ZFF originated from $P$. nicotianae, not from culture media or other exogenous factors. Identification of the specific autoinducer responsible for communal behaviors of $P$. nicotianae is warranted to uncover the exogenous signal source affecting zoospore chemical communication and the mechanism of plant infection by zoosporic pathogens in nature, which could facilitate the development of new control strategies for these pathogens.

\section{ACKNOWLEDGMENTS}

We thank M. Stefani and P. Richardson for reading this manuscript. This work is supported in part by a grant to C. Hong from USDACSREES (2005-51101-02337).

\section{LITERATURE CITED}

1. Bassler, B. L., and Losick, R. 2006. Bacterially speaking. Cell 125:237246.

2. Bush, E. A., Hong, C. X., and Stromberg, E. L. 2003. Fluctuations of Phytophthora and Pythium spp. in components of a recycling irrigation system. Plant Dis. 87:1500-1506.

3. Byrt, P. N., Irving, H. R., and Grant, B. R. 1982. The effect of cations on zoospores of the fungus Phytophthora cinnamomi. J. Gen. Microbiol. 128:1189-1198.

4. Clarke, D. D. 1966. Factors affecting the development of single zoospore colonies of Phytophthora infestans. Trans. Brit. Mycol. Soc. 49:177-184.

5. Deacon, J. W. 1996. Ecological implications of recognition events in the pre-infection stages of root pathogens. New Phytol. 133:135-145.

6. Deacon, J. W., and Donaldson, S. P. 1993. Molecular recognition in the homing responses of zoosporic fungi, with special reference to Pythium and Phytophthora. Mycol. Res. 97:1153-1171.

7. Dijksterhuis, J., and Deacon, J. W. 2003. Defective zoospore encystment and suppressed cyst germination of Phytophthora palmivora caused by transient leaching treatments. Antonie Van Leeuwenhoek Int. J. Gen. Mol. Microbiol. 83:235-243.

8. Donaldson, S. P., and Deacon, J. W. 1992. Role of calcium in adhesion and germination of zoospore cysts of Pythium-A model to explain infection of host plants. J. Gen. Mol. Microbiol. 138:2051-2059.

9. Erwin, D. C., Bartnicki-Garcia, S., and Tsao, P. H. 1983. Phytophthora: Its Biology, Taxonomy, Ecology, and Pathology. American Phytopathological Society, St. Paul, MN.

10. Erwin, D. C., and Ribeiro, O. K. 1996. Phytophthora Diseases Worldwide. American Phytopathological Society, St. Paul, MN.

11. Farr, D. F., Rossman, A. Y., Palm, M. E., and McCaray, E. B. 2008. Fungal Databases. Systematic Mycology and Microbiology Laboratory, ARS, USDA. http://nt.ars-grin.gov/fungaldatabase/.

12. Fraedrich, S. W., Tainter, F. H., and Miller, A. E. 1989. Zoospore inoculum density of Phytophthora cinnamomi and the infection of lateral root-tips of shortleaf and loblolly-pine. Phytopathology 79:1109-1113.

13. Gallegly, M. E., and Hong, C. 2008. Phytophthora: Identifying Species by Morphology and DNA Fingerprints. American Phytopathological Society, St. Paul, MN.

14. Greenburg, E. P., Hastings, J. W., and Ulitzer, S. 1979. Induction of luciferase synthesis in Beneckea harveyi by other marine bacteria. Arch. Microbiol. 120:87-91.

15. Gubler, F., Hardham, A. R., and Duniec, J. 1989. Characterizing adhesiveness of Phytophthora cinnamomi zoospores during encystment. Protoplasma 149:24-30.

16. Halsall, D. M., and Forrester, R. I. 1977. Effects of certain cations on formation and infectivity of Phytophthora zoospores. 1. Effects of calcium, magnesium, potassium, and iron ions. Can. J. Microbiol. 23:994-1001.

17. Hardham, A. R. 2007. Cell biology of plant-oomycete interactions. Cell. Microbiol. 9:31-39.

18. Hogan, D. A. 2006. Talking to themselves: Autoregulation and quorum sensing in fungi. Eukaryotic Cell 5:613-619.

19. Hong, C. X., and Epelman, G. 2001. Effect of pathogen concentration and exposure frequency on Phytophthora blight of annual vinca under drip irrigation systems. (Abstr.) Phytopathology 91(suppl.):S40.

20. Hong, C. X., and Moorman, G. W. 2005. Plant pathogens in irrigation water: Challenges and opportunities. Crit. Rev. Plant Sci. 24:189-208.

21. Irving, H. R., Griffith, J. M., and Grant, B. R. 1984. Calcium efflux associated with encystment of Phytophthora palmivora zoospores. Cell Calcium 5:487-500.

22. Joint, I., Tait, K., and Wheeler, G. 2007. Cross-kingdom signalling: Exploitation of bacterial quorum sensing molecules by the green seaweed Ulva. Phil. Trans. Roy. Soc. B. Biol. Sci. 362(1483):1223-1233.

23. Judelson, H. S., and Blanco, F. A. 2005. The spores of Phytophthora: Weapons of the plant destroyer. Nat. Rev. Microbiol. 3:47-58.

24. Kamoun, S., van West, P., deJong, A. J., deGroot, K. E., Vleeshouwers, V., and Govers, F. 1997. A gene encoding a protein elicitor of Phytophthora infestans is down-regulated during infection of potato. Mol. PlantMicrobe Interact. 10:13-20.

25. Ko, W. H., and Chan, M. J. 1974. Aggregation of Phytophthora capsici zoospores and their interaction with zoospores of P. palmivora. J. Gen. Microbiol. 80:3.

26. Kong, P., Hong, C. X., Jeffers, S. N., and Richardson, P. A. 2003. A species-specific polymerase chain reaction assay for rapid detection of Phytophthora nicotianae in irrigation water. Phytopathology 93:822-831.

27. Kong, P., Lee, B. W. K., Zhou, Z. S., and Hong, C. X. 2010. Zoosporic plant pathogens produce bacterial autoinducer-2 that affects Vibrio harveyi quorum sensing. FEMS Microbiol. Letts. 303:55-60.

28. Latijnhouwers, M., Ligterink, W., Vleeshouwers, V., van West, P., and Govers, F. 2004. A G alpha subunit controls zoospore motility and virulence in the potato late blight pathogen Phytophthora infestans. Mol. Microbiol. 51:925-936.

29. Mitchell, D. J., and Kannwischer-Mitchell, M. E. 1983. Relationship of inoculum density of Phytophthora species to disease incidence in various hosts. Pages 259-269 in: Phytophthora: Its Biology, Taxonomy, Ecology, and Pathology, D. C. Erwin, S. Bartnicki-Garcia, and P. H. Tsao, eds. American Phytopathological Society, St. Paul, MN.

30. O'Toole, G., Kaplan, H. B., and Kolter, R. 2000. Biofilm formation as microbial development. Annu. Rev. Microbiol. 54:49-79.

31. Reid, B., Morris, B. M., and Gow, N. A. R. 1995. Calcium-dependent, genus-specific, autoaggregation of zoospores of phytopathogenic fungi. Exp. Mycol. 19:202-213.

32. Ribeiro, O. K. 1978. A Source Book of the Genus Phytophthora. J. Cramer Press, Germany.

33. Roetschi, A., Si-Ammour, A., Belbahri, L., Mauch, F., and Mauch-Mani, B. 2001. Characterization of an Arabidopsis-Phytophthora pathosystem: Resistance requires a functional PAD2 gene and is independent of salicylic acid, ethylene and jasmonic acid signalling. Plant J. 28:293-305.

34. von Bodman, S. B., Bauer, W. D., and Coplin, D. L. 2003. Quorum sensing in plant-pathogenic bacteria. Annu. Rev. Phytopathol. 41:455-482.

35. von Broembsen, S. L., and Charlton, N. D. 2000. Repeated zoospore emergence by several Phytophthora spp. found in irrigation water. (Abstr.) Phytopathology 90(suppl.):S81.

36. von Broembsen, S. L., and Deacon, J. W. 1996. Effects of calcium on germination and further zoospore release from zoospore cysts of Phytophthora parasitica. Mycol. Res. 100:1498-1504.

37. von Broembsen, S. L., and Deacon, J. W. 1997. Calcium interference with zoospore biology and infectivity of Phytophthora parasitica in nutrient irrigation solutions. Phytopathology 87:522-528.

38. Warburton, A. J., and Deacon, J. W. 1998. Transmembrane $\mathrm{Ca}^{2+}$ fluxes associated with zoospore encystment and cyst germination by the phytopathogen Phytophthora parasitica. Fungal Genet. Biol. 25:54-62.

39. Waters, C. M., and Bassler, B. L. 2005. Quorum sensing: Cell-to-cell communication in bacteria. Annu. Rev. Cell. Dev. Biol. 21:319-346. 